\title{
ANALISIS PERSEPSI WISATAWAN NUSANTARA DAN WISATAWAN MANCANEGARA MENGENAI MITIGASI BENCANA DAN MINAT BERKUNJUNG DI TWA GUNUNG TANGKUBAN PARAHU
}

\author{
Lia Yuliani ${ }^{(1)}$, Wanjat Kastolani ${ }^{(2)}$, Fitri Rahmafitria $^{(3)}$ \\ (1)(2)(3) Program Studi Manajemen Resort \& Leisure \\ Universitas Pendidikan Indonesia \\ liayln88@gmail.com
}

\begin{abstract}
ABSTRAK
TWA Gunung Tangkuban Parahu memiliki banyak potensi alam dan sebanding dengan resiko bencananya sedangkan minat berkunjungnya tetap tinggi. Menurut Bongkosh (2007) "safety were the most important travel motivations". Dalam menentukan keamanan tersebut wisatawan harus memiliki pengetahuan kebencanaan dan biasanya dapat mempengaruhi minat berkunjung. Peneliti bermaksud untuk meneliti perbandingan persepsi wisatawan nusantara dan wisatawan mancanegara mengenai mitigasi bencana dan minat berkunjung di TWA Gunung Tangkuban Parahu. Metode yang digunakan adalah analisis metode kuantitatif dengan analisis data menggunakan Independent T-Test. Dalam penelitian ini ditemukan perbedaan persepsi antara persepsi wisatawan nusantara dan wisatawan mancanegara. Dari 8 variabel dalam penelitian ini diantaranya 4 variabel memiliki perbedaan persepsi antara kedua belah pihak. Dengan mengetahui letak perbedaan persepsi dari wisatawan nusantara dan wisatawan mancanegara, hal ini menjadi perhatian bagi semua pihak yang terkait terutama pihak pengelola untuk meningkatkan dan menambah fasilitas mitigasi bencana di TWA Gunung Tangkuban Parahu baik secara struktural maupun non struktural supaya mampu mempertahankan minat berkunjung wisatawan.
\end{abstract}

Kata Kunci: Persepsi, Wisatawan, Mitigasi Bencana, Minat Berkunjung, TWA Gunung Tangkuban Parahu

\section{PERCEPTION ANALYSIS OF DOMESTIC TOURISTS AND FOREIGN TOURISTS ABOUT DISASTER MITIGATION AND VISITING INTEREST IN MOUNT TANGKUBAN PARAHU}

\begin{abstract}
TWA Mount Tangkuban Parahu has a lot of natural potential and along with the risk of disaster, meanwhile the interest of visit remains high. According to Bongkosh, 2007 "safety were the most important travel motivations". In determining this safety, the tourist must have knowledge of disaster which can be affect to visiting interest. Researcher intend to Comparing perceptions of domestic tourists and foreign tourists about Disaster Mitigation and Visiting Interest in Mount Tangkuban Parahu. The method used in this research is quantitative method, as well as data analysis using Independent Sample T-ttest. This research proofs some diversity in perception between the foreign tourist and domestic tourist. From 8 research variables, which there are 4 variables that have a difference of perception between the two sides. By knowing the differences in the perception between the foreign tourist and domestic tourist, this is a concern for all parties concerned, especially for the company to improve and add disaster mitigation facilities in TWA Gunung Tangkuban Parahu either structural or nonstructural in order to maintain the interest of tourists visiting.
\end{abstract}


Lia Yuliani, Wanjat Kastolani dan Fitri Rahmafitria: Analisis Persepsi Wisatawan Nusantara dan Wisatawan Mancanegara Mengenai Mitigasi Bencana dan Minat Berkunjung di TWA Gunung Tangkuban Parahu

Keywords: Perception, Tourist, Disaster Mitigastion, Vissiting Interest, TWA Gunung Tangkuban Parahu

\section{PENDAHULUAN}

Menurut UNWTO, jumlah wisatawan dunia pada 2015 yang bepergian mencapai jumlah 1,2 miliar turis. Tingkat kedatangan wisatawan di dunia meningkat 4,4 persen sepanjang tahun 2015 hingga menyentuh angka 1,18 miliar. Di tahun 2015 juga menandakan enam tahun berturut-turut pertumbuhan perjalanan turis dunia yang di atas rata-rata, dengan persentase kedatangan turis internasional meningkat empat persen atau lebih sejak 2010.

Selain itu memasuki 2016 UNWTO mencatat, Asia Tenggara menjadi kawasan dengan pertumbuhan kunjungan wisatawan tertinggi di dunia, sepanjang kuartal I 2016 yaitu mencapai 9,4 persen. Berbeda kuartal I 2015 Asia Tenggara hanya membukukan pertumbuhan kunjungan wisatawan sebesar 4,2 persen. Begitupun pula yang terjadi di Indonesia. Indonesia mengalami kenaikan wisatawan yang cukup tinggi memasuki tahun 2016. Berikut ini adalah dinamika laju pertumbuhan wisatawan mancanegara dalam kurun waktu 2015 hingga 2016.
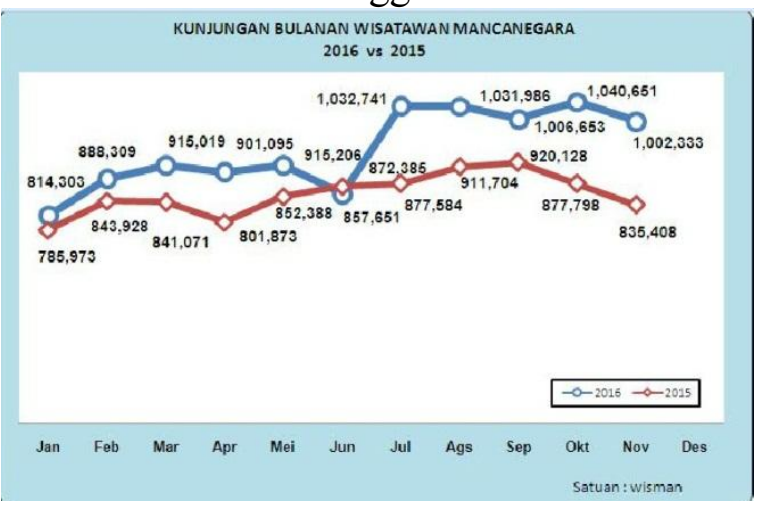

Gambar 1. Kunjungan Bulanan Wisatawan Mancanegra

Sumber : Kementrian Pariwisata (2016)

Dalam sambutannya untuk memperingati World Tourism Day dan Hari Pariwisata Nasional 2015, Menteri Pariwisata RI mengatakan sektor pariwisata pada penghujung tahun 2019 target kunjungan wisman sebesar 20 juta dan wisnus sebesar
275 juta dapat dicapai. Untuk membantu target kunjungan wisatawan di penghujung tahun 2019 sebanyak 20 juta wisman dan 275 wisnus ini setiap daerah di Indonesia harus membantu untuk memperjuangkan target tersebut. Berdasarkan data dari Badan Pusat Statistik (BPS), 11 provinsi yang paling banyak dikunjungi oleh para wisatawan mancanegara salah satunya adalah Jawa Barat.

Jawa Barat memiliki banyak destinasi wisata alam. Salah satu destinasi wisata yang memiliki jumlah kunjungan yang tinggi dari destinasi wisata lain adalah TWA Gunung Tangkuban Parahu. Berikut data kunjungan wisatawan tercatat dari tahun 2012 hingga 2014.

Tabel 1. Daftar kunjungan wisatawan TWA Gunung Tangkuban Parahu

\begin{tabular}{cccc}
\hline Tahun & Wisman & Wisnus & Jumlah \\
\hline 2012 & 28.221 & $1,856,623$ & $\mathbf{1 , 8 8 4 , 8 4 4}$ \\
\hline 2013 & 28.221 & $1,856,623$ & $\mathbf{1 , 8 8 4 , 8 4 4}$ \\
\hline 2014 & 28.221 & $1,856,623$ & $\mathbf{1 , 8 8 4 , 8 4 4}$ \\
\hline
\end{tabular}

Sumber : BPS Provinsi Jawa Barat (2017)

TWA Gunung Tangkuban Parahu ini mampu menjadi respentatif dari destinasi wisata alam lain yang berada di Jawa Barat, karena TWA Gunung Tangkuban Parahu memiliki jumlah wisatawan yang lebih timggi dibandingkan destinasi wisata alam lain di provinsi Jawa Barat.

TWA Gunung Tangkuban Parahu memiliki potensi wisata alam yang beragam. Dari segi sejarah maupun keindahan alamnya. Gunung Tangkuban Parahu memiliki berbagai lokasi kawah yang cukup berdekatan dari kawah ratu, kawah domas dan kawah upas. Namun potensi wisata tersebut beriringan dengan potensi kebencanaannya. Keamanan atas bencana alam yang mungkin saja terjadi di TWA Gunung Tangkuban Parahu memerlukan perhatian lebih. 
Seperti yang dikatakan oleh Bongkosh (2007) "safety were the most important travel motivations". Faktor keamanan merupakan tingkat gangguan/kerawanan keamanan terhadap pengunjung di suatu destinasi wisata alam. Faktor keamanan akan mempengaruhi ketenangan dan kenyamanan wisatawan selama berada di obyek wisata alam tersebut Oleh karena itu keamanan dapat merubah minat berkunjung wisatawan ke destinasi wisata alam itu. Dalam hal menentukan keamanan, wisatawan harus memiliki pengetahuan kebencanaan.

Menurut Humas BNPB bahwa "Secara umum budaya sadar bencana di masyarakat masih rendah. Kita masih sering mengabaikan risiko bencana dalam kehidupan sehari-hari" (www.mediaindonesia.com). Hal tersebut membuat pandangan yang jelas akan pengetahun wisatawan nusantara yang tidak memiliki kepekaan akan risiko bencana termasuk mitigasi bencana. Walaupun mereka mengerti akan keberadaan geografis negaranya yang rawan bencana banyak hal lain yang memiliki resiko tinggi tapi masyarakat Indonesia tidak memperdulikan resiko nya.

Berbeda dengan Negara Jepang yang sudah menanamkan pengetahuan sadar bencana baik disekolah maupun dilingkungan masyarakat. Masyarakat Jepang terbiasa dengan kebiasaan mengecek informasi gempa setiap harinya (Wiwie Tanuwinata, http://www.suarakarya-online.com).

Dilain pihak jumlah wisatawan mancanegara tiap bulannya mengalami kenaikan "Tren 1 juta turis Asing datang ke Indonesia terus berlanut. Selain dari Cina, wisatawan mancanegara yang mendominasi kunjungan ke Indonesia pada Oktober 2016 adalah yang lalu berasal dari Malaysia dengan persentase sebesar 12 persen. Disusul oleh Singapura sebanyak 11,42 persen, Australia sebesar 11,03 persen, dan Jepang sebesar 4,13 persen" (www.katadata.co.id) .

Hal ini menjadi permasalahan baru dimana adanya perbedaan akan kepekaan antara wisatawan nusantara dan wisatawan mancanegara terhadap bencana. Sedangkan semakin tingginya tren kunjungan membuktikan minat wisatwan mancanegara yang tinggi mengartikan kepercayaannya akan keamanan di Indonesia.

Pitana dan Gayatri (2005) menyebutkan keputusan melakukan perjalanan wisata terdapat 5 tahapan yakni : kebutuhan atau keinginan untuk melakukan perjalanan, pencarian dan penilaian informasi, keputusan melakukan perjalanan wisata, persiapan perjalanan dan pengalaman wisata, dan evaluasi kepuasan perjalanan wisata. Dimana tentunya wisatawan memiliki karakter yang berbeda.

Fenomena tersebut menjadi alasan kuat untuk membandingkan persepsi wisatawan terhadap mitigasi bencana dan minat berkunjung supaya menjadi rekomendasi mitigasi bencana yang sesuai berdasarkan pengetahuan kebencanaan wisatawan

Tujuan penelitian dalam Analisis Persepsi Wisatawan Nusantara Dan Wisatawan Mancanegara Mengenai Mitigasi Bencana Dan Minat Berkunjung di TWA Gunung Tangkuban Parahu Membandingkan pengetahuan mitigasi bencana dan minat berkunjung berdasarkan persepsi wisatawan nusantara dan wisatawan mancanegara di TWA Gunung Tangkuban Parahu. Hasil dari penelitian disini mampu mengetahui bagaimana persepsi wisatawan dan minat berkunjung nya di TWA Gunung Tangkuban Parahu dan sebagai acuan untuk meningkatkan minat berkunjung untuk bisa mempertahankannya.

\section{LANDASAN TEORI \\ Mitigasi Bencana}

Menurut Triatmadja (2010) mitigasi bencana terbagi menjadi dua yaitu

1. Mitigasi fisik (struktural) merupakan tindakan-tindakan yang dilakukan secara fisik untuk mengurangi dampak suatu bencana.

2. Mitigasi non fisik (non struktural). merupakan tindakan-tindakan non fisik yang dilakukan untuk mengurangi dampak suatu bencana yang diwujudkan 
Lia Yuliani, Wanjat Kastolani dan Fitri Rahmafitria: Analisis Persepsi Wisatawan Nusantara dan Wisatawan Mancanegara Mengenai Mitigasi Bencana dan Minat Berkunjung di TWA Gunung Tangkuban Parahu

dalam pendidikan mitigasi bencana. Pendidikan mitigasi bencana ini memuat tindakan-tindakan sebelum terjadi bencana (pra bencana), saat terjadi bencana, dan setelah terjadi bencana (pasca bencana).

Tujuan utama (ultimate goal) dari Mitigasi Bencana yaitu sebagai berikut:

1. Mengurangi risiko/dampak yang ditimbulkan oleh bencana khususnya bagi penduduk, seperti korban jiwa (kematian), kerugian ekonomi (economy costs) dan kerusakan sumber daya alam.

2. Sebagai landasan (pedoman) untuk perencanaan pembangunan.

3. Meningkatkan pengetahuan masyarakat (public awareness) dalam menghadapi serta mengurangi dampak/risiko bencana, sehingga masyarakat dapat hidup dan bekerja dengan aman.

\section{Minat Berkunjung}

Menurut Rahayu dan Budiyanto (2004) minat berkunjung ke tempat wisata dipengaruhi oleh:

1. Keinginan berkunjung ke tempat wisata berdasarkan informasi yang di dapat dari media massa.

2. Keinginan berkunjung ke tempat wisata berdasarkan cerita dari keluarga dan sanak saudara

3. Keinginan berkunjung ke tempat wisata karena ingin tahu langsung mengenai tempat wisata tersebut.

Pitana dan Gayatri (2005) menyebutkan bahwa dalam keputusan melakukan perjalanan wisata terdapat 5 tahapan yakni,

1. kebutuhan atau keinginan untuk melakukan perjalanan,

2. pencarian dan penilaian informasi,

3. keputusan melakukan perjalanan wisata,

4. persiapan perjalanan dan pengalaman wisata, dan

5. evaluasi kepuasan perjalanan wisata

\section{METODE}

Lokasi penelitian ini di TWA Gunung Tangkuban Parahu Menurut administrasi pemerintahan kawasan ini termasuk ke dalam wilayah Kecamatan Sagalaherang
Kabupaten Subang dan Kecamatan Lembang, Kabupaten Bandung. Sedangkan secara geografis terletak antara $6^{\circ} 44^{\prime \prime}$ Lintang Selatan dan $107^{\circ} 37^{\prime}$ Bujur Timur Pengumpulan data pada penelitian ini menggunakan data primer (kuesioner) dan data sekunder (studi kepustakaan, dokumentasi dan pencarian data di internet). Populasi pada penelitian ini yaitu wisatawan (wisatawan nusantara dan wisatawan nusantara) yang berkunjung ke TWA Gunung Tangkuban Parahu. Sampel diambil dengan Rumus Slovin menghasilkan hasil sampel berjumlah 144 responden yang terdiri dari 100 responden wisatawan nusantara dan 44 responden wisatawan mancanegara.

Variabel $\mathrm{X}$ dalam penelitian ini adalah Mitigasi Bencana dan Variabel $Y$ adalah Minat Berkunjung di TWA Gunung Tangkuban Parahu. Kuisioner pada penelitian ini menggunakan pendekatan skla likert. Untuk analisis data penelitian ini menggunakan tabulasi data dengan menggunakan Microsoft Excel 2010, perhitungan MSI (Method Success Interval) dan garis kontinum dengan bantuan perhitungan software SPSS. 16.0. Kemudian dilakukan Uji Validitas dan Uji Reliabilitas

Teknis analisis data yang digunakan pada penelitian ini adalah Analisis Independent sample t-test dan uji Hipotesis. Berikut rumus:

Keterangan :

$$
\mathrm{F}=\frac{S 1^{2}}{S 2^{2}}
$$

$\mathrm{F} \quad=$ Nilai $\mathrm{F}$ Hitung

$\mathrm{S}^{2}=$ Nilai varian terbesar

$\mathrm{S}^{2}=$ Nilai varian terkecil

Uji terakhir yang dilakukan adalah Uji hipotesis dengan melakukan Koefisien Determinasi untuk mengetahui seberapa besar pengaruh Variabel $\mathrm{X}$ terhadap Variabel Y, dan Uit untuk menguji

signifikasi koefisien korelasi antara variabel $\mathrm{X}$ dan variabel $\mathrm{Y}$ yang dilakukan dengan membandingkan $t_{\text {hitung }}$ dan $t_{\text {tabel }}$. 
HASIL DAN PEMBAHASAN

Taman Wisata Alam Gunung Tangkuban Perahu berdasarkan Surat Keputusan Menteri Pertanian Nomor : 528/Kpts/Um/9/74 tanggal 3 September 1974 dengan luas kawasan $1.660 \mathrm{Ha}$ yang terdiri atas Cagar Alam seluas 1.290 Ha dan Taman Wisata Alam seluas 370 Ha. Menurut administrasi pemerintahan kawasan ini masuk dalam Kecamatan Sagalaherang Kabupaten Subang dan Kecamatan Lembang, Kabupaten Bandung. Sedangkan secara geografis terletak antara $6^{\circ} 44^{\prime}$, Lintang Selatan dan $107^{\circ} 37^{\prime}$ Bujur Timur.

Secara umum topografi kawasan ini bergelombang dengan lereng yang terjal $30 \%$ - 50\%. Ketinggian tempat mencapai $1.150-2.684 \mathrm{~m}$ dpl. Gunung Tangkuban Perahu mempunyai bentuk seperti perahu terbalik, sehingga nama tersebut sesuai bentuk yang menurut bahasa setempat disebut Tangkuban Parahu yang berarti perahu terbalik.

Berdasarkan klasifikasi dari Schmidt dan Ferguson, iklim pada kawasan ini termasuk tipe iklim B dengan curah hujan rata-rata $2.000-3.000 \mathrm{~mm} /$ tahun. Temperatur berkisar antara $15^{\circ} \mathrm{C}-29^{\circ} \mathrm{C}$ dan kelembaban udara rata-rata $45 \%$ - 97\%.

TWA Gunung Tangkuban Parahu menghasilkan debit air 2,4 m3/detik atau $207.360 \mathrm{~m} 3 /$ hari, dengan kualitas air yang sangat baik (jernih, tidak berbau dengan rasa netral). Sumber air ini dialirkan melalui Sungai Cipanguseupan, Cihaseum, Cikoneng, Cimuja, Ciasem, Cihaji, Cijengkol dan Sungai Cijalu. Daerah Gunung Tangkuban Parahu termasuk dalam wilayah DAS Citarum, Cilamaya, Ciasem dan DAS Cipunagara.

Potensi wisata di TWA Gunung Tangkuban Parahu diantaranya berupa landscape hutan pegunungan yang rimbun akan tumbuhan dan pepohonan yang menimbulkan iklim mikro serta gunung yang sering nampak berkabut serta kaldera kawah Gunung Tangkuban Parahu. Selain itu keindahan panorama pegunungan, hutan, dan perkebunan yang terlihat dari puncak
Gunung Tangkuban Parahu sangat menawan.

Selain itu keanekaragaman flora dan fauna dan keadaan kawasan yang digunakan untuk kegiatan penelitian serta adanya stasiun pengamatan aktivitas gunung berapi milik Pusat Vulkanologi dan Mitigasi Bencana dan Geologi. Ada Nilai Historis, berupa sejarah geologi gunung purba, yaitu Gunung Sunda purba yang setelah meletus sisanya menjadi 3 buah gunung, yaitu Gunung Burangrang, Gunung Tangkuban Parahu dan Bukit Tunggul, serta legenda masyarakat mengenai asal usul Gunung Tangkuban Parahu. Terakhir daya tarik wisata alam (DTWA) adalah Kaldera Kawah Gunung Tangkuban Perahu. Kawah-kawah yang dikembangkan menjadi DTWA yaitu, Kawah Ratu, Kawah Upas dan Kawah Domas.

TWA Gunung Tangkuban Parahu di kelola PT. Graha Rani Putra Persada sebagai pemegang Ijin Pengusahaan Pariwisata Alam seluas $171,40 \mathrm{Ha}$, sesuai dengan Keputusan Menteri Kehutanan No. SK.306/Menhut-II/2009 tanggal 29 Mei 2009 (Periode 2009 - 2039).

Karakteristik pengunjung yang berkunjung ke TWA Gunung Tangkuban adalah untuk wisatawan nusantara pria sebanyak (33\%) dan wanita sebanyak (63\%) dengan usia 18-25 tahun sebesar (74\%), diikuti oleh range usia 26-35 Berdasarkan wisatawan mancanegara pria sebanyak $(54.5 \%)$ dan wanita $(45,5 \%)$. Untuk usia 26 35 tahun $(34,1 \%)$, diikuti oleh responden dengan range usia $18-25$ tahun $(29,5 \%)$. Daerah asal wisatawan mancanegara berasal Malaysia (25\%), lalu kedua di tempati Belanda (20,5\%), setelah itu ada Jerman (15,9\%).

Fasilitas mitigasi yang dimiliki TWA Gunung Tangkuban Parahu diantaranya early warning system, bangunan tahan gempa, BMKG, pagar pembatas kawah, Pusat Informasi, Signage jalur evakuasi, signage meeting point dan penjagaan ketat oleh 33 security (setiap security memegang 1 walkie talkie untuk berkomunikasi) 
Lia Yuliani, Wanjat Kastolani dan Fitri Rahmafitria: Analisis Persepsi Wisatawan Nusantara dan Wisatawan Mancanegara Mengenai Mitigasi Bencana dan Minat Berkunjung di TWA

Gunung Tangkuban Parahu

Persepsi wisatawan nusantara dan wisatawan mancanegara mengenai mitigasi bencana dan minat berkunjung di TWA Gunung Tangkuban Parahu Berikut pada tabel 2 disajikan data rekapitulasi tanggapan responden terhadap mitigasi bencana dan minat berkunjung di TWA Gunung Tangkuban Parahu.

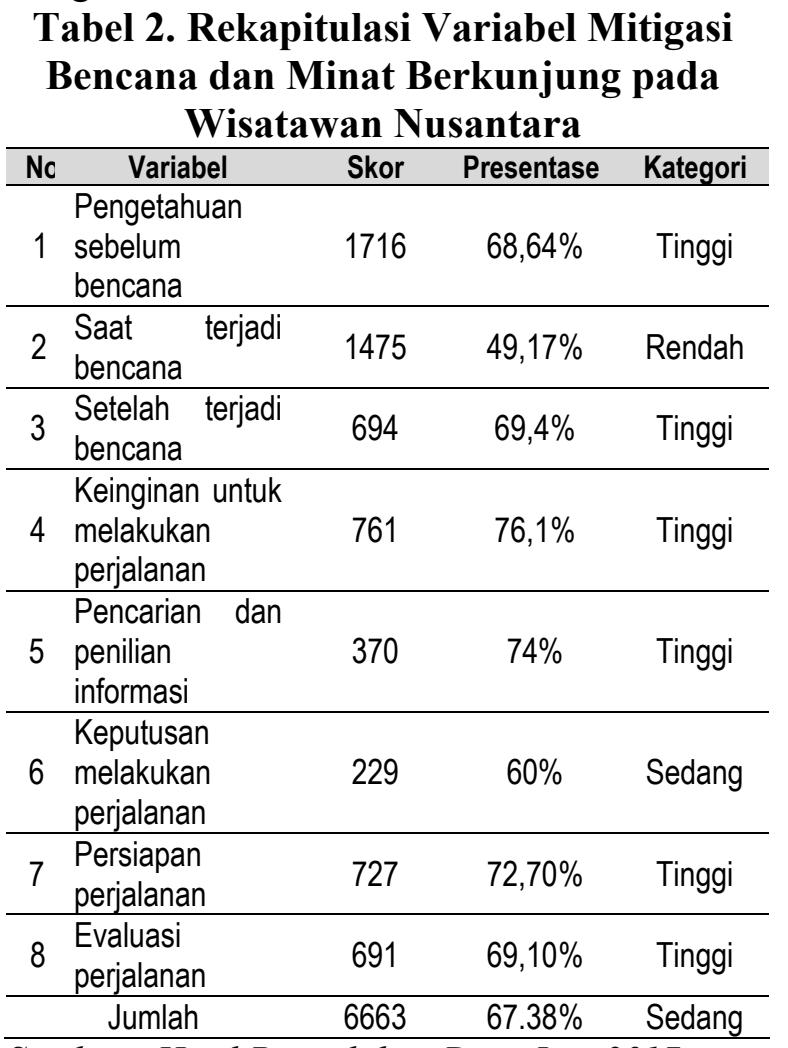

Sumber : Hasil Pengolahan Data Juni 2017

Dari perhitungan Tabel 2 menunjukan nilai yang diperoleh adalah 6663 dari skor ideal yaitu 8000. Maka dapat ditarik kesimpulan bahwa tanggapan responden terhadap mitigasi bencana dan minat berkunjuung di TWA Gunung Tangkuban Parahu bagi wisatawan nusantara masuk kategori sedang.

Tabel 3. Rekapitulasi Variabel Mitigasi

Bencana dan Minat Berkunjung pada Wisatawan Mancanegara

\begin{tabular}{clccc}
\hline No & \multicolumn{1}{c}{ Variabel } & Skor & Presentase & Kategori \\
\hline 1 & $\begin{array}{l}\text { Pengetahuan } \\
\text { sebelum } \\
\text { bencana }\end{array}$ & 701 & $63 \%$ & Sedang \\
\hline 2 & $\begin{array}{l}\text { Saat terjadi } \\
\text { bencana }\end{array}$ & 726 & $55 \%$ & Sedang \\
\hline 3 & $\begin{array}{l}\text { Setelah terjadi } \\
\text { bencana }\end{array}$ & 337 & $77 \%$ & Tinggi \\
\hline 4 & $\begin{array}{l}\text { Keinginan } \\
\text { untuk } \\
\text { melakukan } \\
\text { perjalanan }\end{array}$ & 373 & $85 \%$ & $\begin{array}{c}\text { Sangat } \\
\text { Tinggi }\end{array}$ \\
\hline 5 & $\begin{array}{l}\text { Pencarian dan } \\
\text { penilian } \\
\text { informasi }\end{array}$ & 166 & $75 \%$ & Tinggi \\
\hline 6 & $\begin{array}{l}\text { Keputusan } \\
\text { melakukan } \\
\text { perjalanan }\end{array}$ & 146 & $66.36 \%$ & Sedang \\
\hline 7 & $\begin{array}{l}\text { Persiapan } \\
\text { perjalanan }\end{array}$ & 332 & $75.45 \%$ & Tinggi \\
\hline 8 & $\begin{array}{l}\text { Evaluasi } \\
\text { perjalanan }\end{array}$ & 335 & $76 \%$ & Tinggi \\
\hline Jumlah & 3116 & $71,6 \%$ & Tinggi \\
\hline
\end{tabular}

Sumber : Hasil Pengolahan Data Juni 2017

Dari perhitungan Tabel 3 dapat menunjukan nilai yang diperoleh adalah 3116 dari skor ideal yaitu 4400. Maka dapat ditarik kesimpulan bahwa tanggapan responden terhadap mitigasi bencana dan minat berkunjuung di TWA Gunung Tangkuban Parahu pada wisatawan mancanegara masuk kategori tinggi.

Tabel 4. Hasil T Test Perbandingan Wisatawan Nusantara Dan Wisatawan Mancanegara

\begin{tabular}{|c|c|c|c|c|c|c|c|}
\hline \multirow{3}{*}{\multicolumn{2}{|c|}{ Dimensi }} & \multicolumn{4}{|c|}{ Kelompok } & \multirow{3}{*}{$\begin{array}{l}\text { Sig (2 } \\
\text { tailed) }\end{array}$} & \multirow{3}{*}{ Keterangan } \\
\hline & & \multicolumn{2}{|c|}{$\begin{array}{l}\text { Wisatawan } \\
\text { Nusantara }\end{array}$} & \multicolumn{2}{|c|}{$\begin{array}{c}\text { Wisatawan } \\
\text { Mancanegara }\end{array}$} & & \\
\hline & & $\mathbf{x}$ & sb & $\mathbf{x}$ & $\mathrm{Sb}$ & & \\
\hline $\mathrm{X} 1$ & Pengetahuan sebelum terjadi bencana (pra bencana) & 3.82 & .583 & 3.37 & .410 & .000 & Berbeda \\
\hline $\mathrm{X} 2$ & Pengetahuan saat terjadi bencana & 3.15 & .590 & 3.70 & .612 & .000 & Berbeda \\
\hline $\mathrm{X} 3$ & Pengetahuan setelah terjadi bencana & 3.657 & .738 & 4.23 & .763 & .000 & Berbeda \\
\hline Y1 & Keinginan melakukan perjalanan & 3.66 & .830 & 4.21 & .732 & .000 & Berbeda \\
\hline $\mathrm{Y} 2$ & Pencarian dan penilaian informasi & 3.66 & .924 & 3.39 & .956 & .181 & Tidak Berbeda \\
\hline Y3 & Keputusan melakukan perjalanan wisata & 3.40 & .943 & 3.17 & .945 & .590 & Tidak Berbeda \\
\hline Y4 & Persiapan perjalanan wisata & 3.66 & .773 & 3.73 & .645 & .812 & Tidak Berbeda \\
\hline Y5 & Evaluasi perjalanan & 3.53 & .767 & 3.50 & .670 & .649 & Tidak Berbeda \\
\hline
\end{tabular}

Sumber : Hasil Pengolahan Data Juni 2017 
Keterangan:

\section{: Ada perbedaan persepsi}

Dari Tabel 4 di atas dapat dilihat bahwa setelah dilakukan uji beda, pada masing-masing ke 8 variabel mengenai mitigasi bencana dan minat berkunjung ternyata memang terdapat perbedaan pada skor antara wisatawan nusantara dan wisatawan mancanegara, diantaranya pada pengetahuan sebelum terjadi bencana, saat terjadi bencana, pengetahuan setelah terjadi bencana dan 1 variabel dari minat berkunjung yakni keinginan untuk melakukan perjalanan.Sedangkan untuk 4 variabel lainnya. Yaitu pencarian dan penilaian informasi, keputusan melakukan perjalanan wisata, persiapan perjalanan wisata dan evaluasi perjalanan.

Dari tabel diatas, peneliti akan mengklasifikasikan variabel mana saja yang memang telah terjadi perbedaan persepsi kedua belah pihak. Berikut beberapa variabel (Pengetahuan Mitigasi Bencana) di TWA Gunung Tangkuban Parahu.

\section{Pengetahuan sebelum terjadi bencana}

Pada variabel ini terdapat perbedaan skor, yang membuktikan bahwa telah terjadi perbedaan persepsi antara wisatawan nusantara dan wisatawan mancanegara. Skor yang diperoleh dari kelompok wisatawan nusantara masuk pada kategori tinggi, sedangkan skor yang diperoleh dari kelompok wisatawan mancanegara masuk pada kategori sedang. Jika dilihat dari persepsi wisatawan nusantara, pengetahuan mengenai kebencanaan Indonesia mudah sekali didapatkan. pengetahuan mengenai karakteristik dari bencana di TWA Gunung Tangkuban Parahu pun mampu diketahui. Sehingga wajar saja jika skor sebelum terjadi bencana lebih tinggi pada kelompok wisatawan nusantara. Berbeda dengan persepsi pengetahuan wisatawan mancanegara, yang tidak terlalu memahami pengetahuan kebencanaan Indonesia. Seperti pengetahuan wilayah Indonesia adalah rawan bencana, dan karakteristik bencana di TWA Gunung Tangkuban Parahu. Hal yang

\section{: Tidak ada perbedaan persepsi}

menjadi faktor pengetahuan wisatawan mancanegara dibawah wisatawan nusantara dikarenakan informasi yang biasanya di sebarkan ke ranah internasional adalah informasi yang besar namun tidak terlalu mendetail. Seperti hanya dijelaskan bahwa telah terjadi gunung meletus dengan kekuatan berapa skala richter,ditutup dengan penjelasan jumlah korban jiwa. Berbeda dengan informasi yang disebarkan secara nasional yang bersifat terus menerus dari mulai gunung berapi memasuki siaga 1 hingga masuk pada kategori awas sampai meletus dan masih banyak informasi lainnya. Sehingga pengetahuan sebelum terjadi bencana wisatawan nusantara lebih baik ketimbang wisatawan mancanegara. Mengikuti Surat Edaran Mendiknas Republik Indonesia Nomor 70a/MPN/SE/2010 bahwa banyak sekolah di Indonesia yang sudah menjalankan Sekolah Sadar Bencana, menunjukan bukti bahwa hal ini menjadi perhatian serius pemerintah untuk mengurangi resiko bencana secara sistematis dan sistemik. Pemerintah telah memahami bahwa upaya pencegahan bencana, dan pengurangan resiko bencana perlu dimulai dengan penyebaran informasi dan pengetahuan Hal ini menjadi salah satu alasan wisatawan nusantara memiliki pengetahuan tambahan mengenai kebencanaan. Namun dari indikator mengenai perlunya arahan dari pengelola, wisatawan nusantara dan wisatawan mancanegara menginginkan adanya arahan mengenai kebencanaan bagi wisatawan yang berkunjung ke TWA Gunung Tangkuban Parahu. Arahan tersebut merupakan bentuk mitigasi aktif yang tertuang dalam Peraturan Kepala Badan Nasional Penanggulangan Bencana Nomor 4 tahun 2008 tentang Pedoman Penyusunan Rencana Penanggulangan Bencana.

\section{Pengetahuan saat terjadi bencana}

Pada variabel ini terdapat perbedaan skor, yang membuktikan bahwa telah terjadi 
Lia Yuliani, Wanjat Kastolani dan Fitri Rahmafitria: Analisis Persepsi Wisatawan Nusantara dan Wisatawan Mancanegara Mengenai Mitigasi Bencana dan Minat Berkunjung di TWA Gunung Tangkuban Parahu

perbedaan persepsi antara wisatawan nusantara dan wisatawan mancanegara. Skor yang diperoleh dari kelompok wisatawan nusantara adalah rendah, sedangkan skor yang diperoleh dari kelompok wisatawan mancanegara adalah sedang. Jika dilihat dari persepsi wisatawan nusantara, wisatawan nusantara masih sangat kurang pengetahuannya mengenai cara penyelamatan dan terlihat dari jawaban pada indikator mengenai tingkat kepanikan. Mereka banyak yang menjawab sangat panik. Hal tersebut bisa membuat fokus hilang sehingga akan sulit menyelamatkan diri saat bencana terjadi. Sedangkan persepsi wisatawan mancanegara lebih baik walaupun hal yang wajar saat merasa terancam dan akhirnya merasa panik. Wisatawan mancanegara masuk dalam kategori sedang, setidaknya hal ini menjadi bukti bahwa wisatawan mancanegara sedikit mampu mengontrol fokus apabila terjadi bencana. Lalu ada indikator mengenai pengetahuan titik kumpul (meeting point) dan jalur evakuasi saat terjadi bencana. Wisatawan nusantara memiliki pengetahuan yang masih rendah ketimbang wisatawan mancanegara. Hal berikut terlihat dari data skor yang didapat bahwasannya wisatawan nusatara berada pada kategori rendah untuk kedua indikator ini dan wisatawan mancanegara ada pada kategori sedang.Mengingat jalur evakuasi memang sudah ada namun peta dari jalur evakuasi tersebut tidak disertakan. Walaupun dalam sebuah tanya jawab dengan petugas TWA Gunung Tangkuban Parahu berpendapat bahwa destinasi wisata ini aman karena selalu di pantau pihak keamanan. Jika terjadi aktivitas dari gunung itu akan langsung di informasikan oleh pusat informasi dan dilaporkan ke pusat sehingga tidak akan diadakan kegiatan disekitar kawah sesuai radius yang ditentukan. TWA Gunung Tangkuban Parahu pun sudah memberhentikan aktivitas wisata setiap harinya sampai pukul 16.00 WIB karena pada pukul 17.00 WIB wilayah wisata harus sudah bersih dari wisatawan. Hal-hal tersebut merupakan bentuk kesiapsiagaan bencana sesuai yang tertuang dalam Peraturan Kepala Badan Nasional Penanggulangan Bencana Nomor 4 tahun 2008 tentang Pedoman Penyusunan Rencana Penanggulangan Bencana.

\section{Pengetahuan setelah terjadi bencana}

Pada variabel ini terdapat perbedaan skor, yang membuktikan bahwa telah terjadi perbedaan persepsi antara wisatawan nusantara dan wisatawan mancanegara. Pada indikator mengenai wisatawan akan menghubungi nomor telepon penting seperti rumah sakit, polisi, pemadam kebakaran, dan PLN. Kelompok wisatawan mancanegara mengenal lebih mengenai emergency first response. Layanan ini tersedia di beberapa Negara khususnya eropa. Sehingga kelompok wisatawan mancanegara sudah terbiasa dan mengerti saat terjadi bencana, mereka akan menghubungi pihak tersebut. Ini merupakan faktor Penilaian di kelompok wisatwan mancanegara lebih tinggi ketimbang wisatwan nusantara walalupun tidak terlalu berbeda jauh. Namun Selain indikator itu, ada indikator mengenai meyakini bahwa destinasi wisata alam di Indonesia ini akan memperbaiki sistem mitigasi bencana setelah terjadi bencana. Wisatawan nusantara memiliki persepsi di kategori sedang sedangkan wisatawan mancanegara berada pada kategori tinggi. Hal ini menunjukan bahwa wisatawan mancanegara mempercayai pemerintahan Indonesia bahwa setelah terjadi bencana dibutuhkan pembangunan mitigasi bencana yang lebih baik lagi baik secara struktural maupun non struktural. Pembangun struktural yang bisa diterapkan di TWA Gunung Tangkuban Parahu diantaranya pembangunan bangun kokoh akan gempa, pembangunan pembatas kawah yang lebih baik lagi, di buat jalur evakuasi supaya membuat wisatawan mampu mengurangi rasa paniknya karena mengetahui pilihan untuk menyelamatkan diri dengan menggunakan jalur evakuasi. Untuk non struktural yakni berupa pengetahuan mitigasi bencana. Seperti 
diadakannya arahan terlebih dahulu sebelum memasuki kawasan kawah mengenai karakteristik bencana dari TWA Gunung Tangkuban Parahu, pengarahan mengenai teknik penyelamatan diri beserta penjelasan mengenai nomor-nomor penting yang bisa dihubungi bila mana terjadi kecelakaan atau sesuatu yang tidak diinginkan dan bersifat fatal di wilayah destinasi wisata ini.

\section{Keinginan melakukan perjalanan}

Pada variabel ini terdapat perbedaan skor, yang membuktikan bahwa telah terjadi perbedaan persepsi antara wisatawan nusantara dan wisatawan mancanegara. Skor yang diperoleh dari kelompok wisatawan nusantara adalah tinggi, sedangkan skor yang diperoleh dari kelompok wisatawan mancanegara adalah sangat tinggi. Jika dilihat dari persepsi kelompok wisatawan nusantara bahwa kelompok ini memiliki minat yang besar untuk mengunjungi TWA Gunung Tangkuban Parahu terbukti setiap weekend, destinasi wisata ini seperti lautan manusia yang dipadati oleh wisatawan nusantara. Kegiatannya pun bermacammacam dari hanya menikmati pemandangan, berfoto maupun makan-makan saja bersama keluarga. Skor yang sangat tinggi di dapat wisatawan mancanegara Membuktikan kelompok wisatawan mancanegara memiliki tingkat minat berkunjung yang tinggi berkunjun ke TWA Gunung Tangkuban Parahu. Dari berbagai penjuru dunia yang ingin menikmati keindahan kawah disini merupakan sebuah keinginan yang tinggi. Wisatawan mancanegara yang banyak dijumpai adalah wisatawan asal Belanda, seperti kita tahu bahwa Belanda adalah Negara yang menjajah Indonesia 350 tahun. Bentuk kunjungan mereka menjadi sebuah momen flashback dan ingin menjalin kekeluargaan. Terbukti dari seluruh wisman yang sering peniliti jumpai, wisatawan Belanda adalah wisatwan yang paling ramah dan sangat menerima kita dengan baik.

Tabel 5. Hasil Hipotesis

\begin{tabular}{|c|c|c|c|c|c|c|c|c|c|}
\hline \multicolumn{10}{|c|}{ Independent Samples Test } \\
\hline & & $\begin{array}{r}\text { Leve } \\
\text { Tes } \\
\text { Equa } \\
\text { Varia }\end{array}$ & $\begin{array}{l}\text { e's } \\
\text { or } \\
y \text { of } \\
\text { ces }\end{array}$ & $\begin{array}{r}\text { t-te } \\
\text { Equa } \\
\mathrm{Me}\end{array}$ & $\begin{array}{l}\text { st for } \\
\text { lity of } \\
\text { ans }\end{array}$ & \multicolumn{4}{|c|}{ t-test for Equality of Means } \\
\hline & & \multirow[t]{2}{*}{$\mathbf{F}$} & \multirow[t]{2}{*}{$\begin{array}{l}\text { Si } \\
\text { g. }\end{array}$} & \multirow[t]{2}{*}{ t } & \multirow[t]{2}{*}{ df } & \multirow[t]{2}{*}{$\begin{array}{l}\text { Sig. } \\
(2- \\
\text { tailed) }\end{array}$} & \multirow[t]{2}{*}{$\begin{array}{c}\text { Mean } \\
\text { Difference }\end{array}$} & \multirow[t]{2}{*}{$\begin{array}{l}\text { Std. Error } \\
\text { Difference }\end{array}$} & $\begin{array}{l}95 \% \text { Confidence } \\
\text { Interval of the } \\
\text { Difference }\end{array}$ \\
\hline & & & & & & & & & Lower \\
\hline \multirow[t]{2}{*}{ persepsi } & $\begin{array}{l}\text { Equal } \\
\text { variances } \\
\text { assumed }\end{array}$ & 26.536 & .000 & 3.691 & 142 & .000 & .39335 & .10657 & .18269 \\
\hline & $\begin{array}{l}\text { Equal } \\
\text { variances } \\
\text { not } \\
\text { assumed }\end{array}$ & & & 4.823 & 141.953 & .000 & .39335 & .08156 & .23213 \\
\hline
\end{tabular}

Sumber : Hasil Pengolahan Data Juni 2017

Pengujian hipotesis ini bertujuan untuk menentukan tingkat signifikansi dari sebuah data. Dalam pengujian ini, terdapat uji terhadap dua sisi dengan tingkat signifikansi yakni sebesar $\alpha=5 \%$. Tingkat signifikansi sebesar $5 \%$ atau dalam desimalnya adalah sebesar 0,05 ini merupakan ukuran standar yang paling sering digunakan dalam penelitian. Selanjutnya adalah untuk menentukan $t_{\text {hitung dapat dilihat pada tabel }}$ nilai $t_{\text {tabel }}$ pada lampiran. Sehingga dapat ditentukan:

Tingkat signifikansi $\alpha=5 \%(0,05)$

\begin{tabular}{ll}
$\mathrm{t}_{\text {tabel }}$ & \multicolumn{1}{c}{$=1,97681$} \\
$\mathrm{t}_{\text {hitung }}$ & $=3,691$ \\
Sig & $=0,000$ \\
Hipotesis & $:$
\end{tabular}


Lia Yuliani, Wanjat Kastolani dan Fitri Rahmafitria: Analisis Persepsi Wisatawan Nusantara dan Wisatawan Mancanegara Mengenai Mitigasi Bencana dan Minat Berkunjung di TWA Gunung Tangkuban Parahu

$\mathrm{H}_{0} \quad$ : Tidak ada perbedaan yang nyata pada persepsi wisatawan nusantara dan wisatawan mancanegara terhadap mitigasi bencana dan minat berkunjung di TWA Gunung Tangkuban Parahu

$\mathrm{H}_{1}$

: Ada perbedaan yang nyata pada persepsi wisatawan nusantara dan wisatawan mancanegara terhadap mitigasi bencana dan minat berkunjung di TWA Gunung Tangkuban Parahu

Kriteria penolakan hipotesisnya adalah :

1) Jika $t_{\text {hitung }} \geq t_{\text {tabel }}$ maka ditolak dan diterima.

2) Jika $t_{\text {hitung }} \leq t_{\text {tabel }}$ maka diterima dan ditolak.

atau

1) Jika Sig. $<\alpha(0,05)$ maka ditolak dan diterima.

2) Jika Sig. $\geq \alpha(0,05)$ maka ditolak dan diterima.

Dari kriteria penolakan hipotesis tersebut, maka dapat diketahui keputusan uji sig $(0,000)<\alpha(0,005)$ dan nilai $(3,691)>$ (1,97681). Maka keputusan uji karena sig < $\alpha$ atau $>$ keputusannya ditolak dan diterima.

Kesimpulannya adalah ada perbedaan nyata pada persepsi wisatawan nusantara dan wisatawan mancanegara.

\section{KESIMPULAN}

Peneliti melakukan penelitian analisis persepsi wisatawan nusantara dan wisatawan mancanegara mengenai mitigasi bencana dan minat berkunjung di TWA Gunung Tangkuban Parahu

Dari segi fasilitas terdiri fasilitas early warning system (sirine dan toa), bangunan tahanm gempa, BMKG, pagar pembatas kawah, Pusat Informasi, Signage jalur evakuasi, signage meeting point dan penjagaan ketat oleh 33 security (setiap security memegang 1 walkie talkie untuk berkomunikasi)
Persepsi wisatawan nusantara terhadap pengetahuan sebelum terjadi bencana mendapatkan skor tinggi (68\%). Skor tersebut ada pada kategori tinggi yakni pada rentang 68\%-84\% Namun pada pengetahuan saat tejadi bencana dan setelah terjadi bencana, skor wisatawan nusantara tidak lebih besar dari wisatawan mancanegara. Wisatawan nusantara mendapatkan skor sebesar (49\%) yang masuk dalam kategori rendah ,untuk pengetahuan saat terjadi bencana, dan $(69 \%)$ untuk pengetahuan setelah terjadi bencana. Sedangkan persepsi wisatawan mancanegara. terhadap pengetahuan sebelum terjadi bencana memiliki skor yang sedang yakni $(63 \%)$. Hal ini menunjukan bahwa wisatawan nusantara sudah paham mengenai pengetahuan sebelum terjadi bencana, mereka menyadari keberadaan nya yang hidup di wilayah rawan bencana. Namun untuk variabel pengetahuan saat terjadi bencana, setelah terjadi bencana dan keinginan melakukan perjalanan, wisatawan mancanegara mendapatkan skor yang lebih tinggi ketimbang wisatawan nusantara. Masing-masing skornya adalah pengetahuan saat terjadi bencana(55\%) masuk dalam kategori sedang yakni rentang 52\%-68\%, dan setelah terjadi bencana $(77 \%)$ Hal ini menunjukan bahwa wisatawan mancanegara lebih memahami pengetahuan mitigasi kesiapsiagaan dalam saat terjadi bencana ketimbang wisatawan nusantara. dan keinginan untuk melakukan perjalanan, wisatawan mancanegara mendapatkan skor yang sangat tinggi sebesar $(85 \%)$ yang berada pada rentang skor $84 \%-100 \%$. Berbeda dengan skor wisatawan nusantara sebesar $(76 \%)$ untuk keinginan melakukan perjalanan. Terlihat dari aktivitas yang dilakukan wisatawan mancanegara yang cenderung mengengelilingi seluruh sudut TWA Gunung Tangkuban Parahu. Mencoba menikmati keindahan dari berbagai lokasi wisata di TWA Gunung Tangkuban Parahu. Oleh karena itu wisatawan mancanegara sulit ditemukan di keramaian atau dekat tempat peristirahatan. Mereka cenderung 
menikmati perjalanan wisata yang dilakukan. Sedangkan wisatawan nusantara selain mudah ditemukan karena jumlahnya yang banyak, mereka pun selalu berada di lokasi yang memiliki fasilitas pelayanan. Hal ini menunjukan bahwa wisatawan mancanegara memiliki keinginan yang tinggi melakukan perjalanan wisata dibandingkan wisatawan nusantara. Namun dari hasil keseluruhan mampu dilihatt bahwa perbedaan persepsi pada mitigasi bencana antara wisatwan nusantara dan wisatawan mancanegara yang lebih tinggi pada kelompok wisatawan mancanegara tidak membuat minat berkunjung rendah namun, keduannya memiliki minat berkunjung yang sama-sama tinggi terhadap TWA Gunung Tangkuban Parahu

Terjadi perbedaan yang nyata antara persepsi wisatawan nusantara dan wisatawan mancanegara mengenai mitigasi bencana dan minat berkunjung di TWA Gunung Tangkuban Parahu ( $\left.\mathrm{t}_{\text {hitung }}: 3,691\right)$.

\section{DAFTAR PUSTAKA}

(2014) Gerakan Sadar Bencana Harus Ditingkatkan. [Online] Tersedia di: http://www.suarakarya-online.com

Arnoldus Dhae (2016). Budaya Sadar Bencana Indonesia Masih Rendah. [Online]. Tersedia di: http://mediaindonesia.com/news/read/ 85087/budaya-sadar-bencanaindonesia-masih-rendah/2016-12-29

Bongkosh (2007). Responding to Disaster: Thai and Scandinavian Tourists' Motivation to Visit Phuket, Thailand. Thailand : Journal of Travel Research, Vol. 46, May 2008, 422-432
BPS Provinsi Jawa Barat. (2014). Data Kunjungan Wisatawan ke Akomodasi dan Objek Wisata di Provinsi Jawa Barat. Badan Pusat Statistik. Bandung. Kementrian Pariwisata. (2016). Seminar Internasional Pariwisata Halal.

Pitana, I. Gede dan Gayatri, Putu G. (2005). Sosiologi Pariwisata. Yogyakarta: Andi Offset

Radianta Triatmadja. (2010). Tsunami: Kejadian, Penjalaran, Daya Rusak, dan Mitigasinya. Yogyakarta: Gajah Mada University Press

Rahayu dan Budiyanto. (2004). Manajemen Pemasaran Pariwisata. Yogyakarta: Graha Ilmu.

Republik Indonesia, Keputusan Menteri Kehutanan No. SK.306/MenhutII/2009 tanggal 29 Mei 2009 (Periode 2009 - 2039).

Republik Indonesia, Keputusan Menteri Pertanian Nomor : 528/Kpts/Um/9/74 tanggal 3 September 1974

Republik Indonesia, Peraturan Kepala Badan Nasional Penanggulangan Bencana Nomor 4 tahun 2008 tentang Pedoman Penyusunan Rencana Penanggulangan Bencana

Republik Indonesia, Surat Edaran Mendiknas Republik Indonesia Nomor 70a/MPN/SE/2010 tentang sekolah siaga bencana

Samosir, Agung (2016). Didominasi Cina Turis Asing Bertahan di Atas 1 Juta. [Online]. Tersedia di: http://katadata.co.id/berita/2016/12/01/ cina-masih-mendominasi-kunjunganwisatawan-asing-pada-oktober-2016

UNWTO. (2009). Handbook on Destination Branding. Madrid, Spain ISBN: 97892-844-1311-9. 